\section{SPORTSKE AKTIVNOSTI KAO POMOĆ U SOCIJALIZACIJI DJECE}

Iskustva iz prakse

Primljeno: rujan, 2018.

Prihvaćeno: studeni, 2018.

UDK 159.922.7:796.035

DOI 10.3935/ljsr.v25i3.263

Darko Krstin ${ }^{1}$

Centar za pružanje usluga u

zajednici Klasje Osijek

SAŽETAK

Prednosti bavljenja sportom mnogostruke su i neosporne. Od najranije dobi igra ima veliku ulogu u fizičkom razvoju djeteta. Od prvih igara loptom do amaterskog i svakodnevnog odlaska na treninge, bez obzira je li riječ o individualnim ili grupnim sportovima, mladi čovjek ima priliku razviti mnoge fizičke i socijalne vještine. $U$ fizičkom razvoju djeteta posebno se razvijaju spretnost, okretnost, brzina, snaga i izdržljivost. Djeca koja su dio sportskog tima, imaju priliku razviti potrebne socijalne vještine, međusobnu povezanost, samopouzdanje i toleranciju. Uče se prevladati tremu ili strah. $U$ vrijeme sveprisutne i svima dostupne informacijsko-komunikacijske tehnologije suočeni smo s negativnim posljedicama korištenja istih. Pretilost, tromost, hiperaktivnost i gubitak pažnje samo su neke od smetnji ili čak bolesti koje zahvaćaju najugroženiji dio populacije, djecu i tinejdžere. Rad će predstaviti primjere sportskih aktivnosti i načine motivacije koji se koriste u Centru za pružanje usluga u zajednici Klasje u Osijeku.

\section{UVOD}

Korištenje naprednih tehnologija i računala u učenju, ali i u slobodno vrijeme, osim neupitnih koristi ima i neželjene posljedice. $U$ zdravstvenom smislu, javljaju se: pretilost, poremećaji krvnog tlaka, dijabetes, problemi s

Darko Krstin, profesor tjelesne i zdravstvene kulture, e-mail: darkokrs2303@gmail.com orcid.org/0000-0001-5608-3667

Ključne riječi:

sportske aktivnosti,

fizičke i socijalne vještine, motivacija. iskustva

iz prakse 481 
vidom, bolesti lokomotornog sustava i motorička nekoordiniranosti. U emocionalnom smislu, poteškoće su različite i kreću se od introvertiranosti i depresije do emocionalne otupljenosti i anksioznosti. Problemi započinju još u predškolskoj dobi jer je sve više djece koja nisu vješta u osnovnim dječjim aktivnostima kao što su vožnja bicikla ili igre s loptom. Zato je u tom periodu važno djecu usmjeravati na igru i sportske aktivnosti. Temeljne potrebe svakog djeteta su kretanje i druženje, a sportska aktivnost omogućit će im da tako usvoje nova motorička znanja i vještine. Pretpostavka je da će djeca koja razviju potrebu za fizičkom/sportskom aktivnosti tu potrebu njegovati i u odrasloj dobi. U radu će biti prikazana osobna iskustva rada s djecom uključenom u aktivnosti iz poludnevnog i cjelodnevnog boravka koje provodi Centar za pružanje usluga u zajednici Klasje Osijek.

\section{ISKUSTVA IZ CENTRA ZA PRUŽANJE USLUGA U ZAJEDNICI KLASJE OSIJEK}

Centar za pružanje usluga u zajednici Klasje Osijek nasljednik je Huttler- Kollhoffer- Monsperger sirotišta koje je počelo s radom davne 1870. godine. Od 1993. do 8. srpnja 2016. Centar je djelovao pod nazivom Dječji dom Klasje. Klasje je danas javna ustanova socijalne skrbi koja skrbi o djeci izvan vlastite obitelji (korisnici su djeca bez roditelja, djeca koju roditelji zanemaruju ili zlorabe svoje roditeljske dužnosti ili djeca smještena u našu ustanovu iz drugih razloga).

Klasje pruža sljedeće socijalne usluge:

1. usluga smještaja (baby odjel, predškolski, školski)

2. usluga poludnevnog boravka

3. usluga cjelodnevnog boravka

4. usluga organiziranog stanovanja uz povremenu podršku

5. usluga savjetovanja i pomaganja primarnim ili udomiteljskim obiteljima

6. usluga savjetovanja i pomaganja djeci i mladima nakon izlaska iz skrbi i djeci smještenoj u udomiteljskim obiteljima

7. usluga savjetovanja i pomaganja posvojiteljskim obiteljima.

U ustanovi su zaposleni odgajatelji, socijalni radnici, psiholozi, medicinske sestre, te administrativni radnici i tehničko osoblje.

Za sve korisnike Centra organizirane su sljedeće slobodne aktivnosti: dramska, folklorna i keramičarska, domaćinska i sportska skupina, pričaonica, botaničari i prirodnjaci, te plesna radionica. Svaka aktivnost ima svog voditelja. U umjetničkim radionicama djeca izrađuju različite proizvode koje prodajemo. Dramska, plesna i folklorna skupina priređuju priredbe kako bi obilježili značajnije datume iz našeg kalendara. Autor rada je voditelj sportske skupine.

\section{2 iskustva iz prakse}


U Centru Klasje svjesni smo uloge sportskih aktivnosti na tjelesno, emocionalno i socijalno zdravlje djece. Dakako, bavljenje sportom znači i korisno ispunjeno slobodno vrijeme, što je također važno u radu s korisnicima. Sportske aktivnosti u Centru Klasje provode se na nekoliko načina i u njih su uključena djeca iz stalnog smještaja i poludnevnog boravka. Nakon početne faze prilagodbe, djeca se upućuju na sportske aktivnosti u klubove po vlastitom odabiru ili sposobnostima, ili im se organiziraju sportske aktivnosti unutar ustanove kao npr. fitnes (rad pod nadzorom) ili sport na vanjskim terenima. Takav način rada odvijao se protekle školske godine u predškolskoj grupi Klasja. Dva puta tjedno vježbano je s djecom na poboljšanju lokomotornog sustava i usvajanju novih motoričkih vještina. Uz to je stavljen naglasak i na zdravu prehranu.

Obuka neplivača zahtijeva dodatnu angažiranost odgajatelja i dobro poznavanje djetetove osobnosti. Odgajatelj ih mora razumjeti i prihvatiti sa svim njihovim poteškoćama i strahovima. Dijete mora imati osjećaj sigurnosti i povjerenja, a odgajatelj mora znati motivirati dijete. $U$ ovom slučaju, djeca dobiju diplomu o završenoj obuci neplivača. Svake godine voditelj sportskih aktivnosti nauči plivati nekolicinu djece, a to ovisi o ukupnom broju djece neplivača. U 2018. godini obučeno je jedanaest korisnika.

S korisnicima usluga Centra Klasje vode se razgovori o važnosti sudjelovanja na nastavi tjelesne i zdravstvene kulture i tako ih se motivira za sudjelovanje $u$ školskim natjecanjima i izvannastavnim sportskim aktivnostima.

\section{POHVALA I NATJECANJE KAO OBLIK MOTIVACIJE KORISNIKA}

U Centru Klasje radimo s korisnicima vrlo različitih obiteljski i zdravstvenih anamneza. Mnogi naši korisnici nemaju dovoljno samopouzdanja, jer imaju lošu sliku o sebi.

U takvim slučajevima izuzetno je važna pohvala. Osim nagrada i slave, snažan vanjski motivator predstavlja i pohvala ljudi u bližoj okolini i ljudi od velikog osobnog značaja (Mentalni trening, 2016.). Pohvalom i razgovorom želimo djeci u Centru Klasja približiti značaj bavljenja sportom jer kroz treninge, druženja, natjecanja, putovanja dolazi do boljeg upoznavanja i razumijevanja svojih, ali i tuđih osjećaja i postupaka. Pojedinac mijenja sliku o sebi, jer je kao dio tima postigao određeni rezultat. To je najbolji način za razvijanje samopouzdanja. Kroz druženja s drugom djecom dolazimo do bolje socijalizacije i uvažavanja drugih. »Često se spominje u radu sa sportašima da zadovoljstvo treba uzeti uz put, ne uz cilj. Uz osjećaj zadovoljstva vezan je još jedan vrijedan unutarnji motiv, a to je osjećaj postignuća. Svaki put 
kad ostvarimo cilj, osjećamo se ispunjeno i sretno jer postižemo nešto za sebe ili svoje bližnje« (Mentalni trening, 2016.).

\section{NATJECANJA}

Početkom nove školske godine započinje i novi ciklus natjecanja za četiri regionalne ustanove socijalne skrbi (Lipik, Slavonski Brod, Vinkovci i Osijek). Natjecanja se održavaju u plivanju, stolnom tenisu, odbojci i nogometu (Tablica 1.). Sudjeluju djevojčice i dječaci. Najava putovanja i natjecanja motivacijski djeluje na djecu i oni se rado odazivaju na ponuđene aktivnosti. Koristeći sve ponuđene sadržaje, voditelj sportskih aktivnosti započinje širi odabir kandidata i proces treninga.

Tablica 1. Natjecanja 4 dječje ustanove Slavonije, 2018. godine

\begin{tabular}{ll}
\hline \multicolumn{1}{c}{ Natjecanje 4 dječje ustanove Slavonije } & Rezultati Klasja, Osijek \\
\hline 1. Plivanje (održano u Slavonskom Brodu) & 2. mjesto \\
\hline 2. Stolni tenis (održano u Lipiku ) & 3. mjesto \\
\hline 3. Nogomet (održano u Osijeku) & 2. mjesto \\
\hline 4. Odbojka (održano u Vinkovcima) & 3. mjesto \\
\hline
\end{tabular}

U zimskom periodu koristimo dobro uređen fitnes prostor u Centru Klasje i odlazimo 1-2 puta tjedno u sportsku dvoranu na mali nogomet. $U$ ovoj aktivnosti sudjeluje petnaest dječaka. Ono što je svakako najveća želja svih dječaka s poludnevnog boravka i stalnog smještaja je sudjelovanje na Svjetskom nogometnom turniru u Republici Poljskoj koje se održava u lipnju ili srpnju svake godine (Tablica 2.). Za odlazak na natjecanje djeca moraju imati pozitivan uspjeh u školi. Odlaskom na tako veliko natjecanje i dalek put, djeca dobivaju puno informacija, sklapaju nova prijateljstva i iskustva koja im kasnije mogu koristiti u životu. Uče se poštenoj igri, toleranciji i korektnom odnosu prema protivniku. Tijekom cijele godine prisutna je i suradnja sa NK Osijekom u projektu »Pokrenimo grad«. Odlaskom na stadion, potičemo korektno navijačko ponašanje bez nasilja. S obzirom na njihovu dob i potrebu identifikacije, pozitivnim ocjenjujemo sudjelovanje profesionalnih nogometaša NK Osijeka u druženju s našim korisnicima. Pokloni koje od NK Osijeka dobije svako dijete povodom rođendana kod djece dodatno razvija osjećaj pripadnosti i ponosa.

\section{4 iskustva iz prakse}


Tablica 2. Međunarodna nogometna natjecanja

\begin{tabular}{lc}
\hline Međunarodne nogometne utakmice u 2017./18. godini & Rezultati \\
\hline 1. Klasje (Hrvatska) - Njemačka & $2: 2$ \\
\hline 2. Rusija - Klasje (Hrvatska) & $3: 1$ \\
\hline 3. Litva - Klasje (Hrvatska) & $4: 0$ \\
\hline 4. Klasje (Hrvatska) - Slovenija & $3: 1$ \\
\hline 5. Klasje (Hrvatska ) - Palestina & $3: 1$ \\
\hline 6. Makedonija - Klasje (Hrvatska) & $0: 4$ \\
\hline 7. Klasje (Hrvatska) - Slovenija & $1: 2$ \\
\hline 8. Klasje (Hrvatska) - Palestina & $0: 1$ \\
\hline 9. Klasje (Hrvatska) - Nizozemska & $0: 4$ \\
\hline 10. Klasje (Hrvatska) - Nepal & $4: 0$ \\
\hline 11. Republika Češka - Klasje (Hrvatska) & $2: 0$ \\
\hline
\end{tabular}

\section{ULOGA ODGAJATELJA U RADU S DJECOM I USPJEHU DJECE}

»Na prvi pogled čini se vrlo jednostavnim definirati ulogu odgajatelja u domskom radu: To je onaj profesor ili gospođa koja u našoj grupi i brine o nama. odgovorit će većina djece u domovima kojima bi se postavilo takvo pitanje« (Žic, 1999:127). Posao odgajatelja zahtijeva kvalitetnu, moralnu i etičnu osobu, ali i visoko empatičnu koja može prepoznati emocije i raspoloženja svojih korisnika. Posao odgajatelja je težak, složen i odgovoran. Zadaća odgajatelja je izvesti dijete na pravi put, pokazati mu kako svojim osobinama i vještinama može uspjeti u životu. Kada raspravlja o ulozi odgajatelja, Žic napominje (1999.: 131): »Osim poznavanja svakog djeteta ponaosob, odgajatelj treba poznavati i grupu, osjetiti kako grupa 'diše'. Senzibilnost na atmosferu grupe omogućila je mnoge nezaboravne trenutke druženja, ali i spriječila mnoge ozbiljne posljedice po pojedinu djecu, a i po cijelu grupu.». Atmosfera grupe vrlo je važna za sve vrste uspjeha, a naročito sportske. Svako dijete mora znati da je važna karika u timu i da će njegovo sudjelovanje doprinijeti uspjehu cijelog tima. Dakako, imajući na umu probleme s kojima djeca dolaze, vrlo je važno koordinirati i kontrolirati njihovo sudjelovanje u grupnim aktivnostima.

Da bi bili uspješni, vrlo je važno dobro planirati svoj rad. Prilikom planiranja moramo uzeti u obzir sve relevantne faktore za provođenje sportskih aktivnosti, od prostora i interesa djece, metoda rada i organizacije natjecanja do vrjednovanja i samovrjednovanja korisnika. Planiranje započinje početkom rujna i ovisi o broju korisnika, njihovom interesu za pojedine aktivnosti i školskim obvezama. Za planiranje sportskih aktivnosti posebno je važna inicijalna provjera onih karakteristika za 
koje pretpostavljamo da se tjelesnom vježbom mogu transformirati. Voditelju sportskih aktivnosti u Centru Klasje najuspješnijim se pokazalo tematsko planiranje, što znači da se korisnici ciljano pripremaju za određene vrste natjecanja. Po kalendaru sportskih aktivnosti, koji zajednički izrađuju četiri ustanove iz Slavonije, razvidno je za koje se aktivnosti mogu pripremati. $\cup$ 2018. godini trideset i devet korisnika redovito je sudjelovalo u nogometu, odbojci, plivanju, stolnom tenisu i međunarodnim natjecanjima (Tablica 3.). Unatoč svim pripremama i željama voditelja i korisnika, uspjeh ponekad izostane. Međutim, »očigledno je stoga, da se smisao posla odgajatelja treba tražiti drugdje, prvenstveno u osobnom zadovoljstvu u obavljanju tog posla. Smisao rada treba biti u samom procesu, radost u radu s djecom, za taj posao treba postojati intrinzična motivacija, želja da se dijeli s djecom privrženost. Bez osobnog osjećaja zadovoljstva u radu s djecom, teško je postići pozitivne rezultate« (Žic,1999:: 131).

Tablica 3. Broj sudionika u sportskim aktivnostima 2018. godine $(N=39)$

\begin{tabular}{lcc}
\hline \multicolumn{1}{c}{ Sport } & Djevojke & Mladići \\
\hline Nogomet & - & 15 \\
\hline Stolni tenis & 2 & 2 \\
\hline Odbojka & 2 & 3 \\
\hline Plivanje & 2 & 2 \\
\hline Obuka neplivača & 7 & 4 \\
\hline Ukupno & 13 & 26
\end{tabular}

\section{ZAKLJUČAK}

U Centru za pružanje usluga u zajednici Klasje Osijek, koja skrbi o djeci izvan vlastite obitelji, uloga sporta je i puno veća, jer on razvija osjećaj pripadnosti i sigurnosti, uspjeha, samopouzdanja i tolerancije. Od predškolskog uzrasta do tinejdžerske dobi, sport je aktivnost koja pomaže oblikovati svako ljudsko biće. Sport promiče zdravf način života, timski duh, razvija disciplinu i potiče stvaranje radnih navika. Vrlo često djeca pronalaze uzore u voditelju sportskih aktivnosti, jer ih on hrabri i podržava i u teškim trenutcima.

\section{LITERATURA}

1. Mentalni trening (2016). Unutrašnja i vanjska motivacija. Preuzeto s: https:// mentalnitrening.com/unutrasnja-i-vanjska-motivacija/ (19.11.2018.).

2. Žic, B. (1999). Neka razmišljanja o ulozi odgojitelja u domskom radu. U: Bašić, J. (ur.), Odgoju domovima - kako dalje. Zagreb: Ministarstvo rada i socijalne skrbi RH, 127-133.

\section{6 iskustva iz prakse}


Darko Krstin

Centre for providing services in community Klasje Osijek

\section{SPORTS ACTIVITIES AS A FORM OF SUPPORT IN THE SOCIALISATION OF CHILDREN}

\section{ABSTRACT}

The benefits of engaging in sports activities are manifold and indisputable. From early on play has an important role in a child's physical development. Starting with the first ball games, engaging in amateur sports or attending daily trainings in individual or team sports, young people have a chance to develop many physical and social skills. In terms of a child's physical development, sport particularly affects the development of skilfulness, agility, speed, strength and endurance. Children who are part of a sports team have the opportunity to build the necessary social skills, interpersonal relationships, confidence and tolerance. They learn how to overcome performance anxiety and fear. Today, with ICT technology being widely available and accessible, we are facing the negative consequences of its use. Obesity, inactivity, hyperactivity and attention deficit are some of the disorders or even diseases affecting the most vulnerable population - children and adolescents. The paper provides examples of sports activities and motivation strategies applied at Centre for providing services in community Klasje Osijek.

Key words: sports activities, physical and social skills, motivation.

\section{(c) $(0)$}

Međunarodna licenca / International License:

Creative Commons Attribution-NonCommercial-NoDerivatives 4.0. 
